Marek Jedliński

Uniwersytet im. A. Mickiewicza w Poznaniu

\title{
Człowiek i historia. \\ Piotra Czaadajewa poszukiwania wiary i wizja Królestwa Bożego
}

\section{MAN AND HISTORY. PIOTR CZAADAJEW'S SEARCH FOR FAITH AND THE VISION OF THE KINGDOM OF GOD}

The aim of the article is an analysis of the life and philosophical output of Piotr Czaadajew - the chief representative of the so-called Golden Age of the Russian culture. Czaadajew's viewpoints represent the whole of Russian religious and philosophical thought that has placed the issue of an individual and history first. Czaadajew was the first Russian philosopher to pose the question of the sense of Russia's existence against the broad ideological background of Christian tradition. According to him, only Catholicism was the power that created history and was able to bring mankind closer to the realization of the Kingdom of God on the earth. His demand to build the Kingdom of the Lord immediately relates to his personal attempts to find a sort of an order in the faith in God. Czaadajew - a melancholic and would-be suicide, saw in Christianity a horizon of hope for both an individual and mankind.

Key words: Christianity, Catholicism, the Kingdom of God, history, Russia.

Stulecie dziewiętnaste przyniosło Rosji wielki rozkwit kultury - literatury pięknej, sztuki i w końcu myśli filozoficznej, ukierunkowanej głównie na religię i historię. Epoka ta nazywana jest złotym wiekiem kultury rosyjskiej. W pierwszej połowie wieku XIX bodaj po raz pierwszy, postawiono najpoważniejsze pytanie o miejsce Rosji w historii 
Antropologia teologiczna

uniwersalnej (pogląd to niemal niepodzielnie panujący w literaturze przedmiotu). Postawieniu tegoż pytania towarzyszyło również ożywienie myśli chrześcijańskiej na gruncie rosyjskim. Fenomen zorientowania myśli rosyjskiej na historię mógłby być wyjaśniany w świetle charakterystycznej dla większości intelektualistów rosyjskich (szczególnie doby romantyzmu) niesystematyczności wykładu i nakierowania na cele praktyczne (otwierające perspektywę anthropos), ujawniając zależność implikacyjną głoszonych poglądów ${ }^{1}$. Jak pisał Mikołaj Bierdiajew, „,autonomiczna myśl rosyjska zrodziła się na podłożu problematyki historiozoficznej"2. Perspektywa anthropos niejako towarzyszy wszelkim, rosyjskim rozważaniom o sensie historii powszechnej i historii Rosji. Myśliciele rosyjscy akcentować będą „uhistorycznienie chrześcijaństwa" i jego głęboki wymiar Bogoczłowieczy - obraz osoby ludzkiej i historii zająl eksponowane miejsce w rosyjskich poszukiwaniach religijno-filozoficznych. Tendencję tę rozpoznał m.in. znawca myśli rosyjskiej - Wasilij Zienkowski: „Filozofia rosyjska [...] zajmuje się głównie człowiekiem, jego losem i drogą, sensem i celami historii"3.

Piotr Jakowlewicz Czaadajew jako pierwszy w myśli rosyjskiej postawił pytanie o sens istnienia Rosji, odwołując się do szerokich nurtów ideowych tradycji chrześcijańskiej. To on był autorem słynnego pierwszego Listu filozoficznego, opublikowanego w czasopiśmie „Teleskop”, w którym poddał kulturę rosyjską druzgocącej krytyce. Spotkała go kara nadzoru psychiatrycznego. Czaadajew udowadniał bowiem, że wielkim błędem cywilizacyjnym było przyjęcie chrześcijaństwa z Bizancjum. Rosyjski myśliciel jedynie katolicyzm uznawał za siłę historiotwórczą, zdolną przybliżyć ludzkość do ziszczenia Królestwa Bożego na Ziemi. Czaadajew był aktywnym polemistą słowianofilów klasycznych, reprezentowanych przez Iwana Kiriejewskiego, Aleksego Chomiakowa i Konstantego Aksakowa. Proponowali oni, by Rosja wzmocniła swą tożsamość narodową poprzez silniejsze odwołanie do tradycji prawosławnej - tożsamość tę budować chcieli jednak w ostrej opozycji wobec katolicyzmu. Postać Czaadajewa odpowiednio scharakteryzował w mowie pogrzebowej właśnie Aleksy Chomiakow:

Refleksja filozoficzna pierwszej połowy wieku dziewiętnastego nie rozwijała się w murach akademickich, a jej reprezentanci nie byli profesorami uniwersytetów. Wiele czynników wpłynęło na taki stan rzeczy. Ważny jest czynnik polityczny: w siermiężnej Rosji uczelnie wyższe nie mogły się stać ośrodkami swobodnej pracy intelektualnej.

M. Bierdiajew, Rosyjska idea, tłum. J. C. i S. W., Fronda, Warszawa 1999, s. 39.

В. В. Зеньковский, История русской философии, Москва 2001, s. 21. 
Prawie wszyscy znaliśmy Czaadajewa, wielu go lubiło i, być może, nikomu nie był tak drogi, jak tym, którzy uważali siebie za jego adwersarzy [...]. Jeszcze droższy był sercu swych przyjaciół z powodu swego bezbrzeżnego, ciągłego smutku, towarzyszącego rzeźwości jego umysłu. Przyczynę tegoż smutku, którego źródło biło nie z prozaicznych, codziennych trosk, lecz ze sfery niematerialnej, znajdujemy w samej biografii i w meandrach jego wnętrza duchowego ${ }^{4}$.

Wspomniany przez Chomiakowa smutek uznać można za słowo - klucz, pozwalający zrozumieć życie i twórczość Czaadajewa. Ów smutek, jakkolwiek wymyślnie nie nazwać stanu psychicznego, znamionującego uczucie przygnębienia, nie tylko określił życie Czaadajewa, lecz nade wszystko wytyczył drogęjego poszukiwań duchowych i intelektualnych. W jednym z listów do dekabrysty Iwana Jakuszkina spod pióra Czaadajewa wyszło zdanie celnie streszczające życie myśliciela: „Taka jest, mój przyjacielu, moja smętna i śmieszna historia”. Ów bywalec salonowy, człowiek o wykwintnych manierach skrzętnie ukrywał przed otoczeniem swój obsesyjny lęk przed śmiercią.

Urodzony w 1794 roku Czaadajew, wcześnie wraz z bratem Michałem osierocony, jako wnuk wybitnego historyka - księcia Michała Szczerbatowa - zdobył znakomite wykształcenie zarówno w domu,jak i na Uniwersytecie Moskiewskim ${ }^{6}$. Przywodząc na pamięć czas spędzony z Piotrem Czaadajewem, jego krewny - Michał Żychariow - napisał: „[...] młodzieniec zeń był nadzwyczaj mądry, oczytany, wykształcony, a nade wszystko dumny i oryginalny"7. Rozczytany w książkach religijnych bibliofil ${ }^{8}$ po studiach wkroczył na drogę kariery wojskowej - wziął udział w kampanii wojennej przeciwko Napoleonowi (dotarł wraz z armią do Paryża), a po zakończeniu działań wojennych jako adiutant generała bywał w salonach petersburskich najwybitniejszych przedstawicieli ówczesnej elity intelektualnej i politycznej, między innymi Mikołaja Karamzina, w salonie którego poznał Puszkina,

А. С. Хомяков, Речь в заседании 28 апреля 1860 года, [w:] Полное собрание сочинений Алексея Степановича Хомякова, t. III, Университетская типография, Москва 1900, s. 454.

П. Я. Чаадаев, И. Д. Якушкину, [w:] tegoż, Полное собрание сочинений и избранные письма, t. II, Москва 1991, s. 122. Zdanie to wypowiedział Czaadajew rok po skandalu wywołanym przez opublikowanie w „Teleskopie” słynnego pierwszego listu filozoficznego, w którym poddawał surowej krytyce Rosję.

Tamże, s. 181.

Zob. М. И. Жихарев, П. Я. Чаадаев, dz. cyt., s. 181-182. 
Antropologia teologiczna stając się dla poety przyjacielem - mentorem ${ }^{9}$. Motywacja powodująca postępowaniem Czaadajewa w wielu przypadkach wydawała się jednak ambiwalentna. Przykładowo, jako kurier carski miał dostarczyć cesarzowi wiadomość o buncie w Pułku Siemionowskim, w którym do niedawna służył. Niewykluczone, że rola posłańca miała przyspieszyć jego karierę ${ }^{10}$. Przeszedłszy w stan spoczynku, zamieszkał w Moskwie (1821 r.) i omal nie stał się działaczem konspiracyjnym. Jednak, zauważywszy zagrożenie, szybko zdystansował się wobec ruchu rewolucyjnego i przez resztę życia pozostawał już wrogiem działań burzących tak rosyjski, jak i zachodni ancien régime.

Życie Piotra Czaadajewa tworzyło mozaikę lęków i wybujałego estetyzmu. Był typowym europejskim dandysem ${ }^{11}$. Żył ponad stan, popadał w coraz większe długi, często powodowało nim znudzenie i dąsy, które stały się powodem opuszczenia loży masońskiej i nie ustawały nawet w trakcie ekskursji zagranicznej ${ }^{12}$. Wasilij Rozanow i Osip Mandelsztam wyprowadzili z tych przywar poglądy filozoficzne Czaadajewa - pierwszy odniósł się doń z drwiną, drugi z pietyzmem: „Współczesnych Czaadajewa zdumiewała jego wyniosłość, a on sam wierzył w swe posłannictwo. Naznaczony był powagą hieratyczną [...]"13. W oczach Mandelsztama majestatyczność filozofa z Basmannej ewokowała wielkość katolickiej idei jedności:

Z tym głębokim, przemożnym pragnieniem jedności, najwyższego stopnia syntezy historycznej zrodził się w Rosji Czaadajew. Choć rodem z równiny, zechciał oddychać powietrzem alpejskich szczytów i [...] poczuł je w swej piersi. Na Zachodzie jest jedność! Z chwilą, kiedy słowa te rozbłysły w świadomości Czaadajewa, nie mógł już sobą rozporządzać i na wieki oddalił się od ,zwykłych” ludzi i trosk ${ }^{14}$.

Por. П. Н. Милюков, Главные течения русской исторической мысли, Москва 1897, s. 289-290; por. Puszkin we wspomnieniach swoich wspótczesnych, tłum. I. Tuwim, J. Stawiński, Warszawa 1955, s. 160; W. Wieresajew, Puszkin żywy, tłum. A. Sarachowa, opr. R. Łużny, Kraków 1978, s. 37, 47.

Zob. В. Я. Богучарский, Три западника сороковыхгодов (П. Я. Чаадаев, В. Г. Белинский и А. И. Гериен). Историко-литературные очерки, Санкт-Петербург 1901, s. 11-12.

Grosman wymienia m.in.: A. Puszkina, A. Gribojedowa, P. Wiazemskiego, M. Lermontowa, I. Turgieniewa. Zob. Л. Гроссман, Пушкин и дендизм, [w:] tegoż, Этюды о Пушкине, Москва - Петроград 1923, s. 7.

Zob. Б. Тарасов, Чаадаев, Москва 1986, s. 40-41.

О. Мандельштам, Петр Чаадаев, [w:] tegoż, Сочинения в двух томах, t. II, Москва 1990, s. 156. 
Czaadajewa poszukiwania historiozoficzne zbiegły się z dramatyczną walką o sens własnego istnienia. Zanim stanie się, u kresu życia, piewcą katolicyzmu, orędownikiem ścisłego porozumienia z Rzymem, doświadczy wielu osobistych kryzysów, związanych z neurozą. Liczne pozostały tego świadectwa w prywatnej korespondencji myśliciela i relacjach mu współczesnych: przykładowo w trakcie podróży po Niemczech tamtejszy medyk zdiagnozował u niego silny rozstrój nerwowy ${ }^{15}$. Przypadków nasileń neurozy było wiele, szczególnie w ostatnich latach życia, co obrazuje list do brata z roku 1850:

Pozwól mi jeszcze słów kilka powiedzieć o starej sprawie, o mojej chorobie [...]. Byłeś przecie świadkiem pierwszego etapu tej choroby, na który złożyły się ataki nerwicowe, w drugim zaś etapie doprowadziły mnie prawie do obłędu. Całe noce spędziłem, biegając po pokoju, otoczony przez swoich ludzi [...]. Niekiedy i całe dni mijały w podobnym stanie ${ }^{16}$.

Czaadajew uprzytomnił sobie, iż tym, co targa jego trzewia, jest choroba duszy. Latem 1825 roku zdecydował się leczyć u wód, w Karlsbadzie, gdzie miał sposobność poznać Schellinga i wdać się z nim w dysputy filozoficzne, mimo iż medycy nakazali mu ograniczyć aktywność umysłową do minimum ${ }^{17}$. Wyjątkowo refleksyjne usposobienie, drobiazgowe pojęciowe wyodrębnianie cech ludzi, zjawisk, neurotyczne teoretyzowanie stały się z czasem ciężkim brzemieniem dla Czaadajewa i mu najbliższych. Urojonym chorobom zaczął towarzyszyć dystans wobec ludzi, doszukiwanie się w ich postępowaniu dwulicowości, a nade wszystko narastające bardzo głębokie przygnębienie.

Czaadajewa najbardziej niepokoiło poczucie upływającego czasu. Wciąż podejmował wysiłek sięgnięcia pod podszewkę czasu fizykalnego, by znaleźć tam usensowniające tło egzystencji. Najczęściej jednak uprzytamniał sobie nieuniknioność konfrontacji z traumatycznym doświadczeniem czasu: „Idea ta [czasu - M. J.] nieustannie jawi się wyłącznie jako brzemię, od którego dusza ludzka pragnie się wyzwolić, jest jarzmem, które usiłuje zrzucić"18. W Listach filozoficznych refleksja nad czasem - jak pisał - dręczyła i napierała nań „ze wszystkich stron, wywołując przygnębienie" ${ }^{19}$. Dyktat monotonnie odmierzanego czasu

Zob. П. Я. Чаадаев, М. Я. Чаадаеву, [w:] tegoż, Полное собрание сочинений и избранные письма, t. II, dz. cyt., s. 19.

16 Tamże, s. 229.

17
Antropologia teologiczna 
Antropologia teologiczna

budził uczucie trwogi i stopniowo przyczyniał się do atrofii woli, zobojętnienia, układania się do „łoża śmierci” bez nadziei ${ }^{20}$. Rodziły się myśli prowadzące do utraty horyzontu sensu, mnożące deprecjonująco brzmiące opinie o własnym życiu, drwiące sądy o ludziach szczęśliwych - naiwnych piewcach ignorancji ${ }^{21}$. Samo myślenie stało się dla Czaadajewa przekleństwem. Doznawanie silnych emocji związanych z przeżywaniem czasu w końcu prowadziło ku stanom głębokiego smutku. Jakby poddając się duchowi epoki - romantycznej frenezji sięgnął Czaadajew po książkę o cierpiących na obłęd, w której - jak podkreślił Borys Tarasow - żywo zainteresował go fragment o melancholikach $^{22}$. Tarasow zarysował nader istotny problem: otóż poglądy historiozoficzne myśliciela stanowiły „refleks” typu osobowości. Warto jednak przytoczyć kolejny wyjątek z jego książki:

$\mathrm{W}$ przeciągu kilku lat $\mathrm{w}$ jego duszy zachodziło fundamentalne i niezauważalne dla otoczenia przeobrażenie, wywołane w chwili, kiedy jego oczom ukazała się przepaść między skończonością ('śmiertelnością) jego jednostkowego istnienia a nieskończonością (wiecznością) bytu ${ }^{23}$.

Aby zasypać tę przepaść, Czaadajew począł - jak pisał Tarasow - ,poszukiwać wiary religijnej”, o czym świadczyły kompletowanie nowej biblioteki, wypełnionej książkami o problematyce religijnej oraz podróż do Watykanu ${ }^{24}$.

To właśnie końcowy etap owego smutku, przygnębienia, kiedy Czaadajew - melancholik każdą swą tkanką odczuwał wyobcowanie i pustkę (,мир около меня скудеет и пустеет”"25), pogrążał się w smutku samotności (уныние одиночества) i poczuciu beznadziei (Czaadajew - „kładę się bez nadziei”26) poprowadzi Czaadajewa ku głębokiemu doświadczeniu wiary i ujrzeniu sensu w Bogu. Tymczasem pozbawiona nadziei, zatruta jadem zwątpienia dusza melancholika, zobojętniała wobec teraźniejszości, przeszłości i wyzbytej celu przyszłości,

20 Por. np.: Полное собрание сочинений и избранные письма, t. II, dz. cyt., s. 61, 217, 218, 223, 230.

Por. П. Я. Чаадаев, Отрывки и разные мысли (1828-1850-е годы), [w:] tegoż, Полное собрание сочинений и избранные письма, t. I, Москва 1991, s. 452; Полное собрание сочинений и избранные письма, t. II, dz. cyt., s. 222-223, 252.

Zob. Б. Тарасов,Чаадаев, dz. cyt., s. 154.

Tamże, s. 155-156.

Tamże, s. 111-123, 156.

П. Я. Чаадаев, М. А. Дмитриеву, [w:] tegoż, Полное собрание сочинений и избранные письма, t. II, dz. cyt., s. 246.

П. Я. Чаадаев, М. Я. Чаадаеву, [w:] tegoż, Полное собрание сочинений и избранные письма, t. II, dz. cyt., s. 61. 
stopniowo znikała w bezdennej toni nicości. Melancholik skazany był na „umieranie śmiercią” niechrześcijańską - „straszliwą, wieczną i nieznaną" (Lew Tołstoj) ${ }^{27}$. Dymitr Mereżkowski przytoczył następuAntropologia teologiczna jącą wypowiedź Czaadajewa: „Były chwile, kiedy nie wiedziałem, co ze mną będzie i mimowolnie pojawiała się myśl samobójcza"28. Wiele odpowiedzi w zagadkowej historii życia tego myśliciela daje niemal autobiograficzny poemat Rybacy, którego autorstwo współcześni badacze rosyjscy przypisali właśnie owemu filozofowi ${ }^{29}$. W prostą fabułę poematu (dramat miłosny rybaka Andrzeja) wplątane zostały wątki, które - jeśli uznać autorstwo Czaadajewa za prawdziwe - mogłyby mieć znaczenie autobiograficzne: słowa tworzące nastrój melancholijny, wciąż uobecniające Tanatosa. W kulminacyjnym fragmencie poematu młody rybak Andrzej, nie znalazłszy odpowiedzi na pytanie o sens i cel życia, pragnie zakończyć cierpienie:

Зачем же жить?

Так, так, конец моим страданьям,

Конец надеждам, упованьям...

Есть Днепр!... ${ }^{30}$

Zob. L. Tołstoj, Wojna i pokój, t. IV, tłum. A. Stawar, Warszawa 1979, s. 73.

Д. С. Мережковский, Чаадаев, [w:] tegoż, Невоенный дневник. 1914-1916, Петроград 1917, s. 155.

Należy szczególnie podkreślić zaangażowanie badawcze Wiery S. Greczaninowej (1923-2009), dzięki której odnaleziono w Rosyjskiej Bibliotece Państwowej wiele unikalnych dokumentów historycznych, w tym rzeczone dzieło przypisywane Czaadajewowi. Odkrycie uczonej nabiera szczególnego znaczenia, dając nowe możliwości zrekonstruowania poglądów, biografii, jak również zaproponowania nieco odmiennej (od dotąd w literaturze przedmiotu dominującej) interpretacji myśli, wychodzących spod pióra filozofa z Basmannej. Zdaniem Wadima Sapowa, znawcy tej twórczości, za autorstwem Czaadajewa przemawiają inicjały twórcy (сочинение П.... Ч...ва). Choć liczba opuszczonych liter imienia i nazwiska autora odmienionych w dopełniaczu nie odpowiada ilościowo liczbie liter w imieniu i nazwisku „Piotr Czaadajew”, to nie można wykluczyć, iż był to zabieg celowy. Według Sapowa prócz Czaadajewa nie mogło być innego П.... Ч...вa, który mieszkając w latach 1827-1828 w Moskwie publikowałby w wydawnictwie Siemiona (na karcie tytułowej widnieje następująca informacja: „В типографии Августа Семена, при императорской мед.-хирургической академии 1828"). W dwóch listach do Aleksandra Turgieniewa pojawiał się poruszany przez Czaadajewa wątek wydawnictwa Siemiona i pewnego dzieła, na opublikowaniu którego filozofowi zależało - być może rzecz dotyczyła $R y$ baków (zob. П. Я. Чаадаев, Полное собрание сочинений и избранные письма, t. II, dz. cyt., s. 114-115). Zob. Полное собрание сочинений и избранные письма, t. I, dz. cyt., s. 784-785.

Рыбаки. Повесть в стихах. Сочинение П.... Ч...ва, [w:] П. Я. Чаадаев, Полное собрание сочинений и избранные письма, t. I, dz. cyt., s. 781. 
Antropologia teologiczna

Nad brzegiem Dniepru pojawił się stary rybak, wskazując samobójcy sens i cel:

- Есть Бог, рыбак! К Нему,

К Нему прибегни одному!

Твоя надежда - Бог, Андрей! ${ }^{31}$

Poemat Rybacy wyjaśniałby wiele wątków w biografii filozofa, nade wszystko sytuując i tłumacząc moment przebudzenia religijnego myśliciela, które dało podstawę do zbudowania religijnej konstrukcji historiozoficznej. Proponowana supozycja - o cofnięciu się przed przepaścią, przed unicestwieniem siebie, o gwałtownym wstrząsie, intensywnym doświadczeniu egzystencjalnym, nagłym ujrzeniu horyzontu sensu w wierze religijnej - mogłaby dać odpowiedź na wiele, obecnych w literaturze przedmiotu, pytań o przyczynę tak głębokiego zanurzenia się Czaadajewa w lekturze dzieł Ojców Kościoła i w Biblii. Na lata 1826-1831 przypadły „białe plamy” w biografii myśliciela, szczególnie zaś okryty tajemniczością pustelniczy okres jego życia (lata 1829-1831), o którym zachowało się niewiele świadectw. Warto w tym miejscu przywołać słowa przyjaciółki Czaadajewa - Katarzyny Lewaszowej, skierowane doń, a celnie eksplikujące dwa stany organizujące treść życia i myśl historiozoficzną autora: „,...] przygnębienie i niecierpliwość - to dwie słabości, którym często się pan poddajesz" 32 . Relacja Lewaszowej wskazywać może na istotne źródło koncepcji historiozoficznej Czaadajewa, wyprowadzonej z fragmentu Modlitwy Pańskiej: Adveniat Regnum Tuum.

W liście do dekabrysty Aleksandra Turgieniewa spod pióra myśliciela z Basmannej wyszły słowa explicite wyrażające ideę inspiratywną jego życia i twórczości: „Słowa i czyny moje wypełnione są wciąż rodzącą się jedną tylko myślą: iż wszystko zmierza do celu, a celem tym jest Królestwo Boże"33. Pierwszy List filozoficzny, uwieczniony w pamięci potomnych z powodu odważnej krytyki Rosji, opatrzony został przez autora epigrafem Adveniat Regnum Tuum. Notabene ów fragment Modlitwy Pańskiej po wielekroć pojawiał się w twórczości epistolarnej i aforystycznej Czaadajewa, nierzadko jako epifonem, w różnych okresach jego życia, co potwierdzałoby hipotezę o stałym, porządkującym myśli Czaadajewa, motywie pragnienia szczęścia (jak

\footnotetext{
31 Tamże.

32 Полное собрание сочинений и избранные письма, t. II, dz. cyt., s. 454.

33 П. Я. Чаадаев, А. И. Тургеневу, [w:] tegoż, Полное собрание сочинений и избранные письма, t. II, dz. cyt., s. 96.
} 
pisał: w ujęciu chrześcijańskim, czyli dla sprawiedliwych) ${ }^{34}$. Już na pierwszych stronicach słynnego Listu filozoficznego autor dał wyraz pragnieniu zbudowania „królestwa prawdy wśród ludzi” ${ }^{35}$. Z emfazą Antropologia teologiczna stwierdzał: „W świecie chrześcijańskim wszystko musi z koniecznością przyczyniać się do zaprowadzenia doskonałego ustroju na ziemi i rzeczywiście przyczynia się, inaczej bowiem nie spełniłoby się słowo Pana, iż będzie trwał On w Kościele swoim do schyłku dni" ${ }^{36}$. Zdaniem Czaadajewa, w głośnym wołaniu Adveniat Regnum Tuum zawarta była „cała idea społeczna nauki chrześcijańskiej” ${ }^{37}$. Czas historyczny jawił się dlań jako konieczne medium powrotu upadłego stworzenia do Stwórcy, Królestwo Boże w granicach owego czasu zbudowane przekonywał Czaadajew w zbiorze urywków wypowiedzi i aforyzmów umożliwić miało człowiekowi ponowne znalezienie się w stanie sprzed momentu nadużycia przezeń wolności ${ }^{38}$. Żywe pragnienie powrotu do porządku edenicznego krystalizowało Czaadajewa stanowisko ,antyeschatologizujące”, w osobliwy sposób zresztą uzasadniane: „Prosić Go [Boga-dop. M. J.] o ziszczenie królestwa w niebie pozbawione jest sensu, gdyż królestwo tam nigdy nie przestało istnieć"39.

W oczach Czaadajewa wszyscy kontestujący ziemski wymiar chrześcijaństwa byli w istocie „heroldami rozpadu”. W tym kontekście asceci nieznacznie się odróżniali od ateistów czy anty-teistów: tak pierwsi, jak i drudzy byli równie groźni, siejąc bowiem sceptycyzm (jeśli nie otwartą wrogość) wobec zasadności „urządzeń doczesnych” chrześcijaństwa, rozsiewali ziarno, z którego koniec końców wyrosnąć mogło zwątpienie w sensowność wiary religijnej ${ }^{40}$. W pierwszym Liście filozoficznym

34 Por. Полное собрание сочинений и избранные письма, t. II, dz. cyt., s. 94, 101, 108, 236, 249; por. П. Я. Чаадаев, Отрыьвки и разные мысли, dz. суt., s. 470-471, 477.

P. Czaadajew, Listy filozoficzne, dz. cyt., s. 71.

Tamże, s. 82.

П. Я. Чаадаев, Отрывки и разные мысли, dz. суt., s. 471.

Tamże, s. 470.

Tamże.

Czaadajew tymi słowy w oryginale wyjaśniał znaczenie widzialnego wymiaru Królestwa Bożego: „Реальное, без сомнения, не есть материальное, потому что всякая истинная мысль становится более или менее реальной вне зависимости от того, воплотилась ли она в материю; но не следует забывать, что совершенно реальное, как таковое, способно материализоваться, потомучто совершенная реальность заключает в себе также форму, в которой она должна явиться в свет. Такова, например, любая математическая аксиома, всякая абсолютная истина; так обстояло дело и с истиной христианской, пока она еще не обнаружилась в мире и, на конец, так обстоит дело и сцарством Божием, совершенной реальностью, ещенематериализованной”. Tamże, s. $476-477$. 
Antropologia teologiczna autor przekonywał: „Zupełnie nie rozumie chrześcijaństwa ten, kto nie widzi, że ma ono swój aspekt czysto historyczny, który stanowi jeden z najistotniejszych elementów dogmatu i zawiera w sobie, można powiedzieć, całą filozofię chrześcijaństwa, gdy unaocznia, co dało ono ludziom i co da im w przyszłości" ${ }^{41}$. Dymitr Szachowskoj ${ }^{42}$ - wybitny badacz twórczości Czaadajewa, którego niemal epokowe odkrycie pięciu z ośmiu Listów filozoficznych doprowadziło do reinterpretacji spuścizny myśliciela z Basmannej - zaakcentował Czaadajewowskie wybitnie historyczne widzenie chrześcijaństwa: „cały światowy dramat rozgrywał się dlań na ziemi i wyłącznie żywot ziemski pochłaniał jego myśli" - konstatował Szachowskoj ${ }^{43}$. Pisarza zajmowała nie dogmatyka czy mistycyzm chrześcijański, lecz objawiona człowiekowi w chrystianizmie „nowa treść rozwoju historycznego" 44 .

Czaadajewowskie żądanie ziszczenia Królestwa już „tutaj” (na Ziemi) ewokowało jednocześnie sensowność i celowość zmiany historycznej, ukazując uniwersalność spojrzenia historiozoficznego. Filozof z Basmannej projekt zaprowadzenia Porządku Pańskiego na Ziemi uznał za nadrzędny warunek historiozoficzny jakiegokolwiek rozwoju ludzkości ${ }^{45}$. Myśliciel przekonywał i ostrzegał, iż odrzucenie idei

$41 \quad$ P. Czaadajew, Listy filozoficzne, dz. cyt., s. 81.

42 Książę Dymitr Iwanowicz Szachowskoj (1861-1939) - krewny Piotra Czaadajewa, jeden z czołowych liberałów, wnuk dekabrysty, filolog i polityk (jeden z twórców partii „kadetów”, deputowany Dumy Państwowej, minister). Po rewolucji październikowej poświęcił się pracy naukowej. Szachowskoj niemal przez całe życie badał spuściznę po Czaadajewie. Napisał nadto wiele prac z historii kultury rosyjskiej oraz ruchu demokratycznego i rewolucyjnego w Rosji. Część jego dorobku naukowego zaginęła. Został rozstrzelany przez NKWD w 1939 roku. Więcej o życiu i dorobku naukowym Szachowskoja: И. В. Кузьмина, А. В. Лубков, Князь Шаховской: путь русского тиберала, Москва 2008.

Д. И. Шаховской, Чаадаев Петр Яковлевич. Заметки в тетради, [w:] Философский век. Альманах 26. История идей в России: исследования и материаль, (red.) Т. В. Артемьева, М. И. Микешин, Санкт-Петербург 2004, s. 139.

Tamże, s. 136.

45

W szóstym Liście filozoficznym Czaadajew konfrontował z kolei na sposób apologetyczny ideę Królestwa Bożego, w którym człowiek dokonywał prawdziwego, owocnego ruchu naprzód, zjałowością zarówno umysłowości greckiej (koncepcji cyklologicznych), jak i - pośrednio - teorii postępu sekularnego: „Zamiast się lubować w bezsensownym systemie mechanicznej możności doskonalenia się naszej natury, której w sposób tak oczywisty zaprzecza doświadczenie wszystkich wieków, ludzie byliby w stanie pojąć, że przeciwnie, człowiek pozostawiony samemu sobie zawsze szedł drogą nieskończonej degradacji, i że choć od czasu do czasu bywały epoki postępu u wszystkich narodów, momenty pełnej jasności umysłowej w powszechnym życiu człowieka, podniosłe wzloty rozumu, niebywałe wysiłki ludzkiej natury - temu przecież nie sposób zaprzeczyć - to nic 
Królestwa Bożego na Ziemi oznaczać będzie powrót do „zamkniętego kręgu, do którego niegdyś wciągnięte zostały ludy starożytne i który nieuniknienie połknie ludzkość w całości" ${ }^{46}$. Grecka perspektywa czaAntropologia teologiczna su, bezcelowe powtórzenia stanów z przeszłości pozbawiały nadziei. Zmiana przynosiła wyłącznie śmierć, wciąż odnawiając tragiczny kołowrót, którego nikt nie był władny zatrzymać. Argumentując apologetycznie (nieco na sposób Augustyński), tylko w chrześcijaństwie dostrzegał Czaadajew zakończenie dramatu egzystencjalno-historiozoficznego ${ }^{47}$. Wyłącznie chrystianizm pokonać mógł śmierć, jest on - podkreślał autor - „nade wszystko filozofią życia”48.

Dymitr Mereżkowski tymi słowy streścił istotę poszukiwań intelektualno-duchowych Czaadajewa:

Przyjdź Królestwo Twoje - Adveniat Regnum Tuum - w tych trzech ${ }^{49}$ słowach Modlitwy Pańskiej zawarta była cała filozofia i cała religia Czaadajewa. Powtarzał je nieustannie, kończył nimi swe dzieła literackie i prywatne listy, wszystkie swe uczynki i myśli, do tego stopnia, iż na koniec słowa te stały się dlań powietrzem, dzięki któremu żył, biciem jego serca. Zaiste, nie wypowiedział nic prócz tych trzech słów - ale wypowiedział je tak jak nikt inny wcześniej ${ }^{50}$.

nie wskazuje na stały i nieprzerwany postęp społeczeństwa w ogóle. To tylko w tym jednym nie stworzonym rękami człowieka społeczeństwie [...] widzimy prawdziwy ruch wstępujący, rzeczywistą zasadę stałego postępu i trwania”. P. Czaadajew, Listy filozoficzne, dz. cyt., s. 143.

To w świecie chrześcijańskim, w rodzinie europejskiej - przekonywał filozof z Basmannej - znajdował się „prawdziwy element stałości i postępu, odróżniający świat nowy od świata dawnego". P. Czaadajew, Listy filozoficzne, dz. cyt., s. 146.

П. Я. Чаадаев, Отрыьки и разные мысли, dz. cyt., s. 477.

Św. Augustyn przekonywał, że czas cykliczny gasił pragnienie zatrzymania chwili, uobecnienia wieczności. Charakterystyczne dla pogańskiej cykliczności naprzemienne występowanie nadziei i strachu budziło dojmującą myśl o przemijaniu szczęścia: jasny stan błogości niepostrzeżenie przechodził w ciemń rozpaczy. Najważniejszy argument apologetyczny Augustyna zawarty był w twierdzeniu, iż po przekroczeniu granic czasu cyklicznego, zwróciwszy się w stronę Zbawiciela, człowiek mógł żywić nadzieję na nieskończenie długie trwanie w szczęściu. Por. Św. Augustyn, Państwo Boże, ttum. W. Kubicki, Kęty 1998 , ss. 456-457, 465-468, 543.

П. Я. Чаадаев, Отрыьки и разные мысли, dz. суt., s. 477.

W oryginale Mereżkowski napisał: „w tych czterech słowach”. Zachowując logikę przekładu, zmieniono tekst tłumaczenia z uwagi na fakt, iż w polskim przekładzie fraza Przyjdź Królestwo Twoje składa się z trzech słów, a nie - jak w języku rosyjskim - z czterech (Да приидет Царствие Твое). 
Antropologia teologiczna

Mereżkowski postać Czaadajewa ustawił w szeregu obok Mikołaja Gogola, Lwa Tołstoja czy Włodzimierza Sołowjowa, uzasadniając swój wybór przekonaniem, że wymienionych literatów i myślicieli jednoczyło głośne nawoływanie: „Przyjdź Królestwo Twoje!”. Autor Rewolucji $i$ religii prowokacyjnie stwierdził nawet, że ,w nich wszystkich [...] żywioł religijny łączył się z żywiołem rewolucyjnym"51. Płodem owego osobliwego połączenia miał być „niepokój religijno-rewolucyjny”, bezkompromisowość, niecierpliwość, pragnienie ziszczenia ideału Królestwa Bożego na Ziemi - natychmiast ${ }^{52}$.

Jednakże warunkiem wcielenia idei Królestwa musiało być odbudowanie siły i jedności cywilizacji chrześcijańskiej. W szóstym Liście filozoficznym Czaadajew wyrażał niezmącony optymizm, przekonując, iż chrystianizm „musi podbić świat, nie zatrzyma się ani nie zginie”53. Optymizm ów budował m.in. na argumencie, że mimo pożogi reformacji i rewolucji, mimo aktywności agresywnych ruchów sekularnych, „Europa to wciąż chrześcijaństwo, bez względu na to, co czyni i mówi”, więc - kontynuował - „nie można też wątpić, że któregoś dnia granice dzielące ludy chrześcijańskie znikną ponownie. Kto wie nawet, czy ten dzień nie jest bliższy, niż się wydaje" ${ }^{4}$. Autor Listów filozoficznych wieszczył nadchodzący przełom, definiowany jako powrót Europy do rozwoju opartego na nauce Chrystusowej, jako wielki akt ekspiacji:

Przyjdzie taki czas, proszę mi wierzyć, kiedy rodzaj powrotu do pogaństwa, jaki dokonał się w piętnastym wieku, i nazywanego nader niewłaściwie odrodzeniem literatury, będzie trwał w pamięci tylko [...] jako wspomnienie jakiegoś występnego szaleństwa młodości ${ }^{55}$.

Myśliciel z Basmannej głęboko wierzył w odrodzenie religijne ludzkości. W jego interpretacji ruchy sekularne czy nawrót do pogańskiej przeszłości stanowiły jedynie interludium między jednością religijną z przeszłości a tą oczekiwaną. W szóstym Liście filozoficznym z emfazą stwierdzał:

Nigdy ogół idej rozproszonych na powierzchni świata nie był do tego stopnia skoncentrowany jak w obecnym społeczeństwie; nigdy, w żadnej epoce powszechnych losów istoty ludzkiej, jedna jedyna myśl

Tamże, s. 85.

Por. wypowiedź Katarzyny Lewaszowej o typowej dla Czaadajewa „słabości” - „niecierpliwości”, organizującej jego życie i twórczość. Zob. Полное собрание сочинений и избранные письма, t. II, dz. cyt., s. 454.

P. Czaadajew, Listy filozoficzne, dz. cyt., s. 151.

Tamże, s. 145.

Tamże, s. 148. 
nie obejmowała tak dokładnie całej aktywności jej natury, jak dzisiaj właśnie ${ }^{56}$.

Cykl Listów kończył Czaadajew postulatem przywrócenia jednoAntropologia teologiczna ści świata chrześcijańskiego, niejako ex definitione zawartym w idei szczęścia dla sprawiedliwych w Królestwie Bożym:

Niezwykłe pojmowanie życia przyniesionego na Ziemię przez twórcę chrześcijaństwa, duch poświęcenia, lęk przed podziałem i gorące umiłowanie jedności - oto, co kieruje prawdziwym chrześcijaninem we wszystkim. W ten sposób zachowana zostaje idea objawiona, w ten sposób dzięki tej idei dokonuje się wielkie dzieło połączenia dusz i różnych sił moralnych świata w jedną tylko duszę i w jedną tylko siłę. To połączenie jest wyłączną misją chrześcijaństwa. Prawda jest jedna: Królestwo Boże, niebo na Ziemi, wszystkie obietnice Ewangelii - to nic innego, jak zapowiedź i urzeczywistnienie połączenia wszystkich myśli ludzkości w jedną myśl, i ta jedyna myśl jest myślą samego Boga, to znaczy ziszczonym prawem moralnym. Cała praca świadomości w ciągu stuleci przeznaczona jest na to, by osiągnąć rezultat ostateczny - koniec i cel wszystkiego, ostatnią fazę natury ludzkiej, rozwiązanie dramatu powszechnego, wielką syntezę apokaliptyczną ${ }^{57}$.

Idea „połączenia wszystkich myśli ludzkości w jedną myśl” powzięta była dla ludzkości przez samą Opatrzność, człowiek natomiast ze swej strony ,zawsze odczuwał potrzebę powrotu do stanu pierwotnego zgodnie z idealnym wzorem"58, do życia odznaczającego się „,doskonałością, pewnością, jasnością”, ,jakie posiadał niedawno i jakie obiecane mu jest również w przyszłości" ${ }^{59}$. Posługując się figurą retoryczną, zapytywał autor adresatkę Listu: „A czy Pani wie, co to za życie? To Niebo [...], ostateczny cel ducha w świecie"60. Projekt przywrócenia jedności osadzony był na następującym fundamentum historiozoficznym: upadek człowieka rozbił jedność, oddalając od Boga, odtworzenie jej, czyli powrót do Boga zachodzić miał w czasie historycznym, w którym budowane miało być Królestwo Boże - Królestwo Prawdy.

Osip Mandelsztam w szkicu literackim poświęconym Czaadajewowi konstatację naukową o idei porządkującej konstrukcję historiozoficzną myśliciela z Basmannej ujął w następujących słowach: „Z tą głęboką, nieusuwalną potrzebą jedności, najwyższej syntezy historycznej narodził się w Rosji Czaadajew. Mieszkaniec równiny

\begin{tabular}{ll}
\hline 56 & Tamże, s. 149. \\
${ }_{57}$ & Tamże, s. 178. \\
${ }_{58}$ & Tamże, s. 130. \\
${ }_{59}$ & Tamże, s. 108. \\
${ }_{60}$ & Tamże, s. 108-109.
\end{tabular}


Antropologia teologiczna zechciał oddychać powietrzem alpejskich szczytów i, jak zobaczymy, wyczuł je w swej piersi”"'i. Ideał chrześcijański, jedność w wymiarze historycznym została już osiągnięta, wystarczyło nakierować wzrok na wzorzec z przeszłości. Czaadajew zwracał się ku - jak pisał - „pierwszym chwilom ery chrześcijańskiej" ${ }^{62}$, ku owemu zwornikowi, jakby eskapistycznie wznoszącemu ponad ograniczenia epok. To w nim koncentrował się wszelki czas, zawierał w sobie bowiem początek i koniec wszystkiego, w nim przeszłość rodzaju ludzkiego zmieszana była z przyszłością. Nade wszystko historia wieków średnich była dla tego myśliciela historią jednej, europejskiej rodziny chrześcijańskiej, historią ducha ludzkiego, okresem, kiedy narody, choć podzielone pod względem geograficznym, były jednym ciałem, całością myśli i idei, całością moralną ${ }^{63}$. W średniowieczu - patetycznie pisał Czaadajew - panowała jedność, wszystkie ludy trzymając się za ręce kierowane przez powszechnie wtenczas uznawany autorytet papieski kroczyły naprzód, ku wyznaczonemu celowi. Ludy te nawet w tym samym języku zwracały się do Boga (przez piętnaście wieków), budując „cudowną zgodność dźwięków, tysiąckrotnie wznioślejszą od wszystkich harmonii fizycznego świata" ${ }^{4}$. Na Zachodzie - przekonywał myśliciel - wszystko powstało z chrześcijaństwa, również społeczeństwa nowożytne ideowo przeniknęła nauka Chrystusowa: przykładowo rewolucje polityczne były w istocie rewolucjami duchowymi ${ }^{65}$.

Mandelsztam w przywołanym wyżej szkicu zapisał: „Na Zachodzie jest jedność! Od chwili, kiedy słowa te wybłysły w świadomości Czaadajewa już sobą nie rozporządzał i na wieki oderwał się od prozaicznych ludzi i spraw"66. Sam Czaadajew w końcowych partiach pierwszego Listu filozoficznego oświadczył, że „mimo całej niekompletności, niedoskonałości i wadliwości świata europejskiego w jego dzisiejszej formie, nie można zaprzeczyć, że Królestwo Boże zostało w nim do pewnego stopnia urzeczywistnione"; Europa - przekonywał rosyjski myśliciel - ,posiada w zarodkach i elementach wszystko, co jest konieczne do ostatecznego zapanowania Królestwa Bożego na ziemi”"67. Dla tych

61 О. Мандельштам, Петр Чаадаев, [w:] tegoż, Сочинения в двух томах, t. II, Художественная литература, Москва 1990, s. 152.

P. Czaadajew, Listy filozoficzne, dz. cyt., s. 139.

63 Tamże, s. 145-146.

64 Tamże, s. 83.

65 Tamże, s. 84.

66

P. Czaadajew, Listy filozoficzne, dz. cyt., s. 85. 
wszystkich zdeponowanych w Europie, był to ożywczy pierwiastek jedności. I w rzeczy samej warunkiem osiągnięcia celu rozwoju ludzkości - końcowego etapu procesu dziejowego, czyli powrotu stworzenia Antropologia teologiczna do Stwórcy - tak niecierpliwie wypatrywanego przez Czaadajewa było odbudowanie jedności świata chrześcijańskiego ${ }^{68}$.

Cel procesu historycznego został przez rosyjskiego myśliciela jasno zdefiniowany. Moment zbudowania Królestwa Bożego na ziemi znacznie przybliżało wcześniejsze osiągnięcie stanu jedności świata chrześcijańskiego. Jako że stan ów zaistnieć miał w granicach czasu historycznego, należało poszukiwać ośrodka jednoczącego chrześcijan (wyruszających na misję powrotu do Stwórcy) już tutaj, na ziemi:

Mogę się zgodzić, że papiestwo - pisał Czaadajew - jest [...] instytucją ludzką, jeżeli rzeczy o tym wymiarze mogą pochodzić od człowieka, ale wynika ono zasadniczo z ducha chrześcijaństwa: to widoczny znak jedności, a ponieważ był rozdział, to ponadto znak ponownego zjednoczenia ${ }^{69}$.

Czaadajew, zdając relację ze swej sentymentalnej ekskursji do przeszłości (kiedy ludzie poszukując nadziei na zbawienie, zwracali wzrok w stronę Rzymu), uprzytamniał czytelnikom siłę duchową papiestwa, które mimo ataków ludzi małej wiary

spełnia doskonale swoją misję, ogniskuje myśli chrześcijańskie, przyciąga je wzajemnie do siebie; nawet tym, co negują jedność, przypomina tę najwyższą zasadę ich wiary, i zawsze, dzięki temu charakterowi niebiańskiego powołania, którym jest naznaczone, góruje dostojnie nad światem interesów materialnych ${ }^{70}$.

Droga historyczna katolicyzmu ukazała, iż „dla czystej prawdy to, co zewnętrzne złączone jest $\mathrm{z}$ tym, co wewnętrzne, tak jak w samym Chrystusie [...] pierwiastek ludzki złączony został z Boskim"71.

68 Por. tamże, s. $76,80$.

69 Tamże, s. 155.

70 Tamże, s. 156. Czaadajew dostrzegał znaczenie tendencji sekularnych we współczesnym mu świecie, śmiało twierdząc: „Wyzute ze swego ludzkiego blasku, jest przez jeszcze mocniejsze, a obojętność, którą się dla niego żywi, jeszcze je wzmacnia i lepiej zapewnia mu trwałość [...]. Chociaż dziś na pozór nikt się nie przejmuje zanadto papiestwem, niechby nagle znikło cudem jakimś z kuli ziemskiej - jakiż popłoch ogarnąłby wszystkie wspólnoty religijne, gdyby ten żywy pomnik dziejów wielkiej wspólnoty nie był już pośród nich obecny. Tę widoczną jedność, na której im dziś tak niewiele zależy, będą chciały odnaleźć wszędzie, ale ona nigdzie się nie pojawi”. Tamże, s. 156.

71 П. Я. Чаадаев, Ответ на статью А. С. Хомякова „О сельских условиях”, [w:] tegoż, Полное собрание сочинений и избранные письма, t. I, dz. cyt., s. 544. 
Antropologia teologiczna

Czaadajew konfrontował również katolicką wierność Prawdzie z postawą protestantów:

Czyż nie jest absurdem wyrzucać mu to, że konsekwentnie, żarliwie i z uczuciem wypełniał swe zadanie? Co stałoby się ze światem, gdyby zwątpił pod wpływem różnych herezji, pojawiających się niemal od pierwszego dnia założenia kościoła, a które nie przestały burzyć porządku do chwili, kiedy zostały pochłonięte przez wielką herezję wieku XVI, dążącą do zamienienia widzialnej pełni kościoła na pustkę swojego kościoła niewidzialnego? ${ }^{72}$.

Autor - entuzjasta widzialnej jedności świata chrześcijańskiego omyłkę protestantów wyprowadzał z błędnego interpretowania przez nich słów Pańskich: „Królestwo moje nie jest z tego świata” $(\mathrm{J} 18,33)^{73}$. Sens, który im przypisali protestanci, sprzeczny był ze znaczeniem fragmentu Modlitwy Pańskiej, w którym człowiek błaga, aby wola Boga, czyli Królestwo Pana, ziściła się zarówno w niebie, jak i na ziemi. Tymczasem owi odszczepieńcy, schizmatycy, heretycy, sekciarze - jak nazywał Czaadajew uczniów Lutra - „poczęli tłumaczyć, że Jezus Chrystus [...] miał na myśli niebiosa, że Królestwo Boże jest królestwem niewidzialnym, podobnież jak Jego Kościół, który z woli Bożej panować winien jedynie w sercach ludzi"74. Myśliciel, rzecz jasna, $\mathrm{z}$ pietyzmem traktował Biblię, ale ostrzegał przed zastępowaniem autorytetu hierarchii, tradycji i dyscypliny przez literę Pisma ${ }^{75}$. W historii chrześcijaństwa niepowściągliwa egzegeza tekstu biblijnego, tracąca rozeznanie, co jest wynikiem oddziaływania Ducha Świętego a co wytworem człowieka, stała się źródłem ataków na ideę jedności świata

Tamże, s. 500.

Cytat według Biblii Tysiaclecia.

П. Я. Чаадаев, Полное собрание сочинений и избранные письма, t. II, dz. cyt., s. 236$237,249$.

„Tak, Biblia jest najdroższym skarbem ludzkości, źródłem wszelkiej prawdy moralnej; ona rozlała na świat potoki światła [...]; to jej głównie zawdzięcza ludzkość szczęście i jej prawdopodobnie zawdzięczać będzie kres nieszczęść, które jeszcze nas trapią. Ale strzeżmy się przed stawianiem pisanego słowa tak wysoko, jak na to nie zasługuje, strzeżmy się przed popadnięciem w kult, w bałwochwalstwo wobec litery, strzeżmy się zwłaszcza przed wyobrażeniem sobie, że całe chrześcijaństwo zawarte jest w świętej księdze. Nie, po tysiąckroć nie. Nigdy Boskie słowo nie było uwięzione między dwiema deskami jakiejkolwiek księgi; cały świat nie jest dość obszerny, by je pomieścić; mieszka ono w bezgranicznych obszarach ducha, streszcza się w niewymownym misterium Eucharystii, swe wszechpotężne zdanie nakreśliło na nieprzemijającym pomniku krzyża". P. Czaadajew, Doksiężnej Zofii Mieszczerskiej, [w:] tegoż,Listy, dz. cyt., s. 233-234. Por. П. Я. Чаадаев, Полное собрание сочинений и избранные письма, t. II, dz. cyt., s. 238-239, 245-246; P. Czaadajew, Listy filozoficzne, dz. cyt., s. 176-178. 
chrześcijańskiego i pierwszeństwo następców św. Piotra ${ }^{76}$. Czaadajew nie omieszkał zauważyć, że „spór o władzę papieży wywołał nie kościół grecki, lecz protestanci” - owe „dzieci wieku osiemnastego” i „ojcowie Antropologia teologiczna współczesnych racjonalistów" "7. Autor Listów filozoficznych sytuował protestantów poza Kościołem powszechnym, nie pozostawiwszy im złudzeń, stwierdzał, że „to nie prawda powinna iść na ustępstwa”, gdyż „dla prawomocnego autorytetu ustępstwo oznacza rezygnację z wszelkiej władzy, z wszelkiej aktywnej roli, po prostu unicestwienie" ${ }^{78}$. Czaadajew wieścił nadejście dnia, kiedy schizmatycy powrócą na łono Kościoła-matki w worku pokutnym, posypani popiołem ${ }^{79}$.

Warunkiem niezakłóconego, postępowego ruchu wydarzeń dziejowych ku celowi, rozumianemu jako zaprowadzenie Porządku Pańskiego na Ziemi, było harmonijne działanie wszystkich chrześcijan. Tymczasem - w mniemaniu Czaadajewa - protestanci i im podobni buntownicy konsekwentnie deprecjonując katolicką jedność osiągniętą w wiekach średnich, jednocześnie zauroczeni pogańskim antykiem, aktywnie uczestniczyli w tworzeniu mitu epoki odrodzenia - epoki rzekomego triumfu ducha ludzkiego, a w rzeczywistości ukrytego buntu stworzenia wobec Stwórcy, źródła podziału wśród ludzi. Kościół powszechny - przekonywał Czaadajew - bliski był już zbudowania jedności dzięki aktywności Rzymu. Gdyby nie bunt Lutra, postęp przyniósłby płód w postaci Królestwa Bożego na Ziemi. Autor Listów filozoficznych pisząc o postępie, po wielekroć deklarował, że miał na myśli nadejście Królestwa Pana, a nie wyłącznie doskonalenie się ludzi ${ }^{80}$. Myśliciel oskarżał protestantyzm o wynalezienie postępu sekularnego, jawnie antychrześcijańskiego, oraz - w liście do Fiodora Tiutczewa - o zaprowadzenie anarchii w sferze ducha Zachodu, która z kolei wywołała pożogę rewolucyjną. Wzniecona została ona przez reformację, a potem idee oświeceniowe ${ }^{81}$.

Rosyjski myśliciel doskonałe działanie Opatrzności w historii rozpoznawał nade wszystko w czasach minionych katolickiego Zachodu. Tak upragnioną jedność świata chrześcijańskiego prawie odbudował Rzym chrześcijański w wiekach średnich. Jednak buntownicy (protestanci)

$76 \quad$ P. Czaadajew, Do księżnej Zofii Mieszczerskiej, [w:] tegoż, Listy, dz. cyt., s. 232.

77 Zob. П. Я. Чаадаев, Полное собрание сочинений и избранные письма, t. II, dz. cyt., s. $237,249$.

78 P. Czaadajew, Listy filozoficzne, dz. cyt., s. 175.

79 Tamże, s. 155.

$80 \quad$ Zob. tamże, s. 138, 152.

81 П. Я. Чаадаев, Ф. И. Тютчеву, [w:] tegoż, Полное собрание сочинений и избранные письма, t. II, dz. cyt., s. 212. 
Antropologia teologiczna dokonali rozłamu i cofnęli ludy chrześcijańskie do stanu pogańskiego rozdarcia. Aktywność Rzymu na arenie historii zbliżała do osiągnięcia celu procesu historycznego, rozumianego jako zbudowanie Królestwa Bożego na Ziemi, a jawiącego się jako prefiguracja powrotu upadłego stworzenia do Stwórcy.

Piotr Czaadajew nie miał gruntownego przygotowania teologicznego, jego myśli - z perspektywy nauki katolickiej - mogą się wydawać nieco naiwne i mało oryginalne. Jednak na uwagę zasługuje wyrażane przezeń pragnienie poszukiwania sensu historii uniwersalnej i sensu istnienia człowieka - tak w wymiarze teoretycznym, jak i mocno osobistym, o czym świadczyła wyraźnie autobiograficzna treść poematu Rybacy. Ów sens odnalazł w głębokiej wierze i pragnieniu ziszczenia Królestwa Bożego. Autor z tej perspektywy był dość bezkompromisowy w ocenie dziejów Rosji - uważał, że inercyjne prawosławie oddaliło Rosjan od Boga, od ideału Królestwa. Rosja była w jego oczach ziemią bez historii i bez przyszłości. Nie dokonał jednak konwersji, gdyż czuł się mimo wszystko chrześcijaninem „ponadkonfesyjnym” - wędrowcem, bez stałego miejsca we współczesnym mu świecie. Jego domem była Europa wieków średnich, Europa katolicka.

Słowa kluczowe: chrześcijaństwo, katolicyzm, Królestwo Boże, historia, Rosja. 